\title{
KETAHANAN BEBERAPA VARIETAS PADI TERHADAP PENGGEREK BATANG PADA EKOSISTEM SAWAH MASUKAN BAHAN ORGANIK DAN ANORGANIK
}

\author{
Resistance of some Rice Varieties to Stem Borer in Organic \\ and Inorganic Paddy Ecosystems
}

\author{
Nur Habiba Bahar, Sudirman Numba dan Abdullah \\ Program Studi Magister Agroekoteknologi Universitas Muslim Indonesia \\ Email : bibabahar19@yahoo.com, numbasudirman@yahoo.co.id, abdullahsituru@ymail.com
}

\begin{abstract}
This study aims that knowing the level of resistance of several rice varieties to stem borer in organic and inorganic input paddy ecosystems. The research was conducted in the rice fields of Nonong Village, Batui District, Banggai Regency, from March to June 2020. The research used the Split Plot Design method. The main plot was the rice field ecosystem, namely organic input rice fields and inorganic input rice fields, while the subplots were 4 types of rice varieties, namely: Ciherang, Cisantana, Ciliwung and Towuti. Each treatment unit was repeated three times in order to obtain 24 experimental units. The results showed that the towuti variety planted in the paddy field ecosystem with inorganic input was more resistant to rice stem borer. The intensity of attack and the population of stem borer in the lowland organic matter input ecosystem was higher than the inorganic input lowland ecosystem. There is no interaction between rice varieties and types of paddy ecosystems (input of organic and inorganic materials) on the intensity of stem borer attack and the results of production.
\end{abstract}

Keywords : ecosystem; rice fields; organic, inorganic; rice varieties; stem borer

\section{PENDAHULUAN}

Padi (Oryza sativa L.) merupakan sumber pangan utama bagi masyarakat Indonesia. Permintaan beras semakin meningkat dari waktu ke waktu seiring bertambahnya jumlah penduduk, dengan tingkat konsumsi 114,6 kg/kapita (Kementan 2018).

Produksi beras di Indonesia menurut BPS (2020) bahwa produksi beras mengalami penurunan dari 59,2 juta ton pada tahun 2018 menjadi 54,6 juta ton pada tahun 2019. Menurut Galuh Octania (2020) upaya pemerintah mengatasi penurunan produksi beras melalui impor beras. Di provinsi Sulawesi Tengah produksi beras juga mengalami penurunan yaitu 48,20 ribu ton pada tahun 2019 dibandingkan tahun 2018. Demikian halnya di Kabupaten Banggai, Provinsi Sulawesi Tengah produksi beras mengalami ketidakstabilan dari tahun ke tahun. Pada tahun 2011 produksi 180.100 ton, tahun 2012 turun menjadi 174.457 ton, tahun 2013 turun menjadi 170.542 ton, tahun 2014 naik menjadi 179.165 ton dan tahun 2015 sebanyak 170.953 ton, dan juga pada tahun 2016 mencapai 175.642 ton (BPS, 2017).

Dari data produksi tersebut menunjukkan bahwa kesenjangan antara produksi dan konsumsi masih tinggi sehingga perlu diatasi dengan peningkatan produksi beras. Upaya yang dapat dilakukan 
diantaranya penanaman beberapa jenis varietas padi unggul pada berbagai ekosistem sawah dan pengendalian hama/penyakit secara efektif.

Namun demikian, upaya peningkatan produksi padi berhadapan dengan berbagai masalah dan penghambat berupa faktor abiotis dan biotis. Faktor abiotis yang terpenting berupa penurunan kesuburan lahan, kekeringan dan kondisi iklim dan cuaca yang tidak menentu. Faktor biotis berupa organisme pengganggu tanaman, yaitu hama, penyakit, dan gulma. Dan bila melewati ambang kendali akan merugikan/menurunkan produksi (Kartohardjono, Kertoseputro dan Suryana, 2008)

Salah satu jenis hama pada tanaman padi yang masih menjadi masalah utama adalah penggerek batang padi (Scirpophaga innotata) dan dapat menyerang sepanjang tahun serta menyebar di seluruh Indonesia pada ekosistem padi yang beragam. Intensitas serangan penggerek batang padi pada tahun 2018 mencapai 1,89\% dengan luas daerah yang terserang mencapai 308.753 ha (Ditlin, 2019). Kehilangan hasil akibat serangan penggerek batang pada stadia vegetatif tidak terlalu besar karena tanaman masih dapat mengkonpensasi dengan membentuk anakan baru (sampai dengan 30\%). Namun, bila serangan pada stadia generatif menyebabkan malai berwarna putih dan hampa (tidak berisi) sehingga menurunkan produksi padi (Balai Besar Penelitian Tanaman Padi, 2009). Menurut Harahap dan Tjahjono (1997) penggerek batang padi merupakan hama penting karena mematikan titik tumbuh sehingga mengurangi jumlah anakan dan merusak malai sehingga mengurangi jumlah malai yang dapat dipanen. Selanjutnya menurut Soemartono at al (1981) kerusakan pada tanaman padi muda disebut Sundep dan pada tanaman padi yang sudah berbuah disebut Beluk.

Hama penggerek batang padi (PBP) yang menyerang pertanaman padi di Indonesia terdapat beberapa jenis atau spesies yakni dari famili Pyralidae, yaitu Scirpophaga incertulas Walker (PBP kuning), Scirpophaga innotata Walker (PBP putih), Chilo suppressalis Walker (PBP bergaris), Chilo auricilius Dudgeon (PBP berkilat), Chilo polychrysus Meyrick (PBP berkepala hitam) dan satu jenis dari famili Noctuidae, yaitu Sesamia inferens Walker (PBP merah jambu). Namun demikian dari enam jenis PBP yang terdapat di Indonesia, hanya empat jenis yang sering menyerang tanaman padi, yaitu $S$. incertulas, $S$. innotata, Chilo suppressalis, dan S. inferens. Dari keempat jenis tersebut, penggerek batang padi kuning $S$. incertulas adalah yang paling 
dominan dan paling luas persebarannya di perkembangan hama padi. Penelitian Indonesia (Siwi, 1979; Soehardjan, 1983; Chandramani et al (2010) menyatakan Soejitno, 1986; Sutarna, 1999). bahwa penggunaan bahan organik sebagai

Di Provinsi Sulawesi Tengah, di nutrisi tanaman dapat menurunkan Kabupaten Banggai, jenis penggerek batang keberadaan hama penggulung daun dan padi putih (Scirpophaga innotata Walker) penggerek batang. Selanjutnya hasil merupakan jenis yang dominan dibanding penelitian Chakraborthy (2011) jenis penggerek batang lainnya terutama menunjukkan bahwa ngengat penggerek pada ekosistem sawah intensif atau batang padi dan kelompok telur ditemukan anorganik. Intensitas serangan penggerek paling rendah pada perlakuan dengan bahan batang padi sangat dipengaruhi ekosistem sawah dan musim tanam padi. Penelitiaan Jhonson (2000) menunjukkan bahwa laju tingkat serangan penggerek batang mencapai $74,8 \%$ pada musim kering dan $99,5 \%$ pada musim hujan.

Sistem pertanian organik merupakan suatu metode budidaya tanaman yang berwawasan lingkungan. Prinsip sistem pertanian organik berdasarkan atas interaksi tanah, tanaman, hewan, manusia, mikroorganisme, ekosistem dan lingkungan dengan memperhatikan keseimbangan dan keragaman hayati (Mutiarawati, 2006; Sutanto, 2002). Pemberian pupuk organik selain dapat meningkatkan kesuburan tanah juga dapat menjaga keragaman hayati (musuh alami hama) yang dapat menekan perkembangan hama (Sudiarso, 2003).

Pembudidayaan tanaman padi pada lahan sawah masukan pupuk kandang (organik) diharapkan dapat menekan organik. Selain itu hasil penelitian dari Pajarina (2014) menunjukkan bahwa perkembangan populasi hama wereng coklat, walang sangit, dan wereng hijau pada sistem padi organik lebih rendah dibandingkan dengan sistem padi konvensional.

Berdasarkan uraian di atas maka dilakukan penelitian untuk mengetahui tingkat ketahanan beberapa varietas padi terhadap penggerek batang pada ekosistem sawah masukan organik dan anorganik.

\section{METODE PENELITIAN}

Penelitian ini dilaksanakan di lahan sawah di Desa Nonong, Kecamatan Batui, Kabupaten Banggai, Sulawesi Tengah. Penelitian ini dilakukan pada Maret sampai Juni 2020. Bahan yang digunakan adalah beberapa varietas padi yaitu Ciherang, Cisantana, Ciliwung dan Towuti, pupuk kandang sapi, urea, NPK, dan ZA . Adapun alat-alat yang digunakan yaitu traktor, 
cangkul, label, ember, kertas, timbangan, meter, sabit, mesin pemanenan, dan kamera.

Penelitian ini menggunakan rancangan lingkungan Split Plot Design dengan perlakuan dua faktor. Faktor pertama sebagai petak utama, jenis ekosistem sawah (E) terdiri atas: sawah masukan bahan organik $\left(E_{1}\right)$ dan sawah masukan bahan anorganik $\left(E_{2}\right)$. Faktor kedua sebagai anak petak, yaitu varietas padi (V) yang tediri atas: varietas Ciherang, Cisantana, Ciliwung dan Towuti. Kedua faktor yang diuji menghasilkan 8 kombinasi perlakuan dan setiap kombinasi perlakuan diulang sebanyak tiga kali sehingga diperoleh 24 unit percobaan.

Peubah yang diamati adalah tingkat serangan dan populasi penggerek batang padi

\section{Populasi Hama Penggerek Batang Padi}

Populasi hama penggerek batang diamati dengan menghitung jumlah hama penggerek batang pada saat umur tanaman 65 HST dalam setiap unit perlakuan.

\section{Intensitas Serangan}

Intensitas serangan hama penggerek batang padi diamati dengan menggunakan rumus (Natawigena, 1989):

$$
\text { IS }=\frac{A}{B} \times \mathbf{1 0 0} \%
$$

Keterangan :

IS $=$ Intensitas kerusakan $(\%)$

$\mathrm{A}=$ Jumlah rumpun yang terserang

$B=$ jumlah rumpun per plot

Pengamatan intensitas serangan dilakukan pada fase generatif yaitu saat malai mulai muncul.

\section{Produksi Gabah Kering (kg) per Petak dan Per Hektar}

Gabah yang sudah dipanen dan dikeringkan kemudian ditimbang beratnya per petak, kemudian hasil per petak dihitung ke hasil per hektar dengan rumus:

$$
\begin{gathered}
\text { Hasil }(\mathrm{kg} / \mathrm{ha})=\frac{(\text { luas lahan })}{\text { jarak } \operatorname{tanam}} \times \text { bobot gabah } \\
\text { kering }
\end{gathered}
$$

\section{HASIL DAN PEMBAHASAN}

\section{Populasi Hama Penggerek Batang}

Hasil pengamatan populasi hama penggerek batang menunjukkan bahwa varietas padi berpengaruh sangat nyata terhadap serangan penggerek batang, sedangkan jenis ekosistem sawah berpengaruh tidak nyata. 
Nur Habiba Bahar : Ketahanan beberapa Varietas Padi terhadap Penggerek Batang pada Ekosistem Sawah Masuka Bahan Organik dan Anorganik

Tabel 1. Rata-rata populasi hama penggerek batang pada ekosistem sawah masukan bahan organik dan anorganik.

\begin{tabular}{ccccc}
\hline \multirow{2}{*}{$\begin{array}{c}\text { Varietas } \\
(\mathrm{V})\end{array}$} & Organik $\left(\mathrm{E}_{1}\right)$ & Rnorganik $\left(\mathrm{E}_{2}\right)$ & Rata-rata & Nilai Pembanding \\
\cline { 2 - 3 } & & & & $59,99^{\mathrm{a}}$ \\
\hline $\mathrm{V}_{1}$ & 63,66 & 56,33 & $44,49^{\mathrm{a}}$ & \\
$\mathrm{V}_{2}$ & 46,33 & 42,66 & $40,33^{\mathrm{a}}$ & 33,44 \\
$\mathrm{~V}_{3}$ & 54,66 & 26,00 & $19,66^{\mathrm{b}}$ & \\
$\mathrm{V}_{4}$ & 21,00 & 18,33 & & \\
\hline Rata - rata & 46,41 & 35,83 & &
\end{tabular}

\begin{tabular}{lcl} 
Rata - rata & 46,41 & 35,83 \\
\hline Keterangan: Angka-angka yang diikuti huruf yang sama $(\mathrm{a}, \mathrm{b})$, berbeda tidak nyata pada uji BNJ 0,01
\end{tabular}

Berdasarkan Tabel 1, menunjukkan beberapa varietas padi yang ditanam pada bahwa populasi hama penggerek batang yang ekosistem sawah masukan bahan organik dan menyerang varietas padi ciherang $\left(\mathrm{v}_{1}\right)$ pada anorganik berpengaruh tidak nyata.

ekosistem sawah masukan bahan organik

Berdasarkan Gambar 1, rata - rata maupun anorganik lebih tinggi dan berbeda intensitas serangan pada beberapa varietas nyata dibandingkan dengan varietas ciliwung padi pada ekosistem sawah masukan bahan $\left(\mathrm{V}_{3}\right)$ dan varietas towuti $\left(\mathrm{V}_{4}\right)$, namun berbeda organik $\left(\mathrm{E}_{1}\right)$, menunjukkan kecenderungan tidak nyata dengan varietas cisantana $\left(\mathrm{V}_{2}\right)$. rata - rata intensitas serangan tertinggi yaitu Varietas padi dengan tingkat populasi hama pada varietas ciherang $\left(\mathrm{V}_{1}\right)$ dibandingkan penggerek batang terendah adalah varietas dengan varietas lainnya. Sedangkan pada towuti $\left(\mathrm{V}_{4}\right)$, baik pada ekosistem sawah sawah masukan bahan anorganik $\left(\mathrm{E}_{2}\right)$ masukan organik maupun anorganik.

\section{Intensitas Serangan} cenderung terendah pada varietas towuti $\left(\mathrm{V}_{4}\right)$ dibandingkan dengan varietas lainnya.

Hasil pengamatan intensitas serangan penggerek batang menunjukkan bahwa 
Nur Habiba Bahar : Ketahanan beberapa Varietas Padi terhadap Penggerek Batang pada Ekosistem Sawah Masuka Bahan Organik dan Anorganik

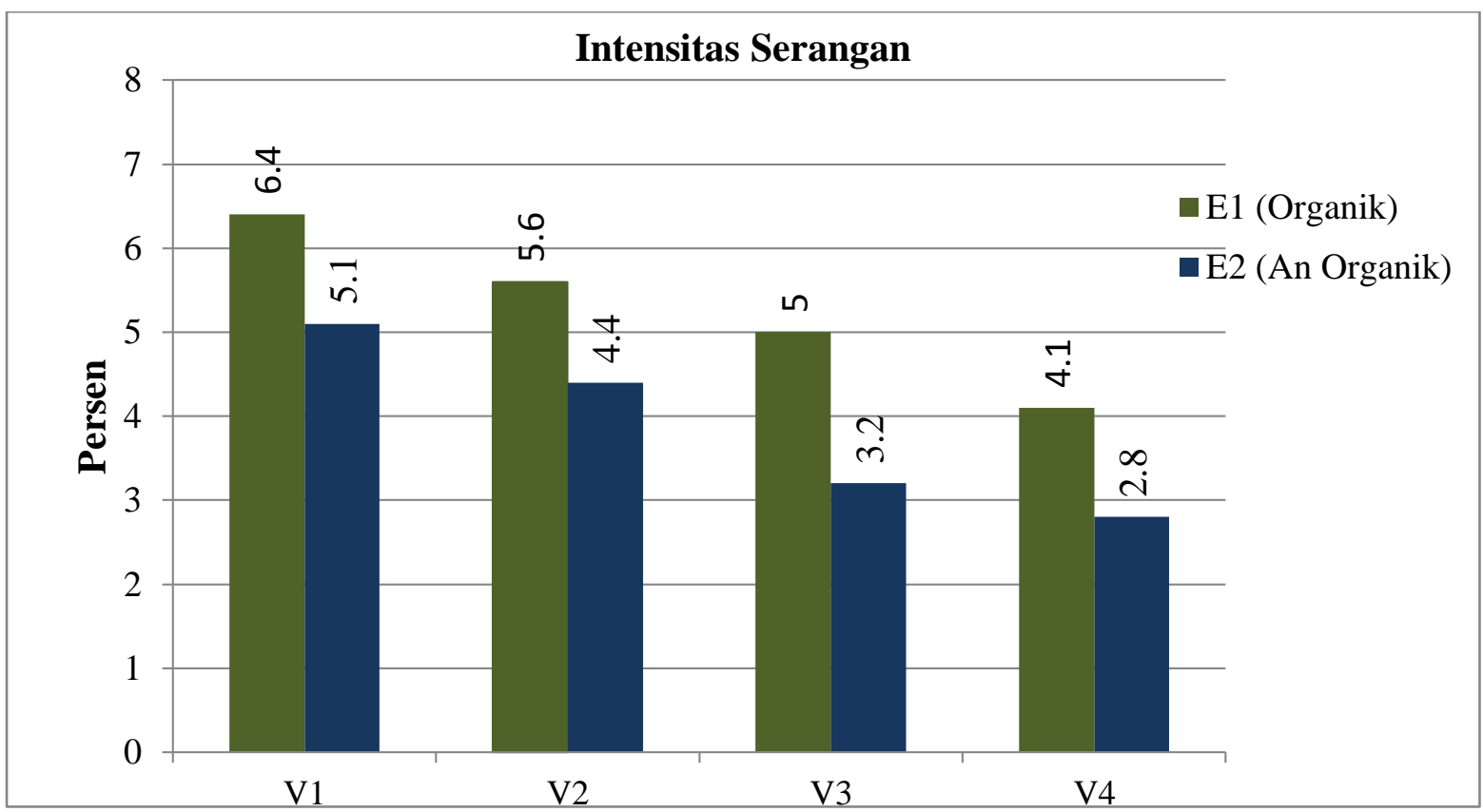

Gambar 1. Rata - rata intensitas serangan beberapa varietas padi pada ekosistem sawah masukan bahan organik dan anorganik.

Pada Gambar 1 juga terlihat bahwa secara umum tingkat atau intensitas serangan penggerek batang lebih tinggi pada semua varietas yang ditanam pada ekosistem sawah masukan bahan organik dibandingkan sawah masukan anorganik.

\section{Produksi Gabah Kering (kg)}

Hasil pengamatan produksi gabah kering per petak menunjukkan beberapa varietas padi dan ekosistem sawah masukan bahan organik dan anorganik berpengaruh tidak nyata. 
Nur Habiba Bahar: Ketahanan beberapa Varietas Padi terhadap Penggerek Batang pada Ekosistem Sawah Masuka Bahan Organik dan Anorganik

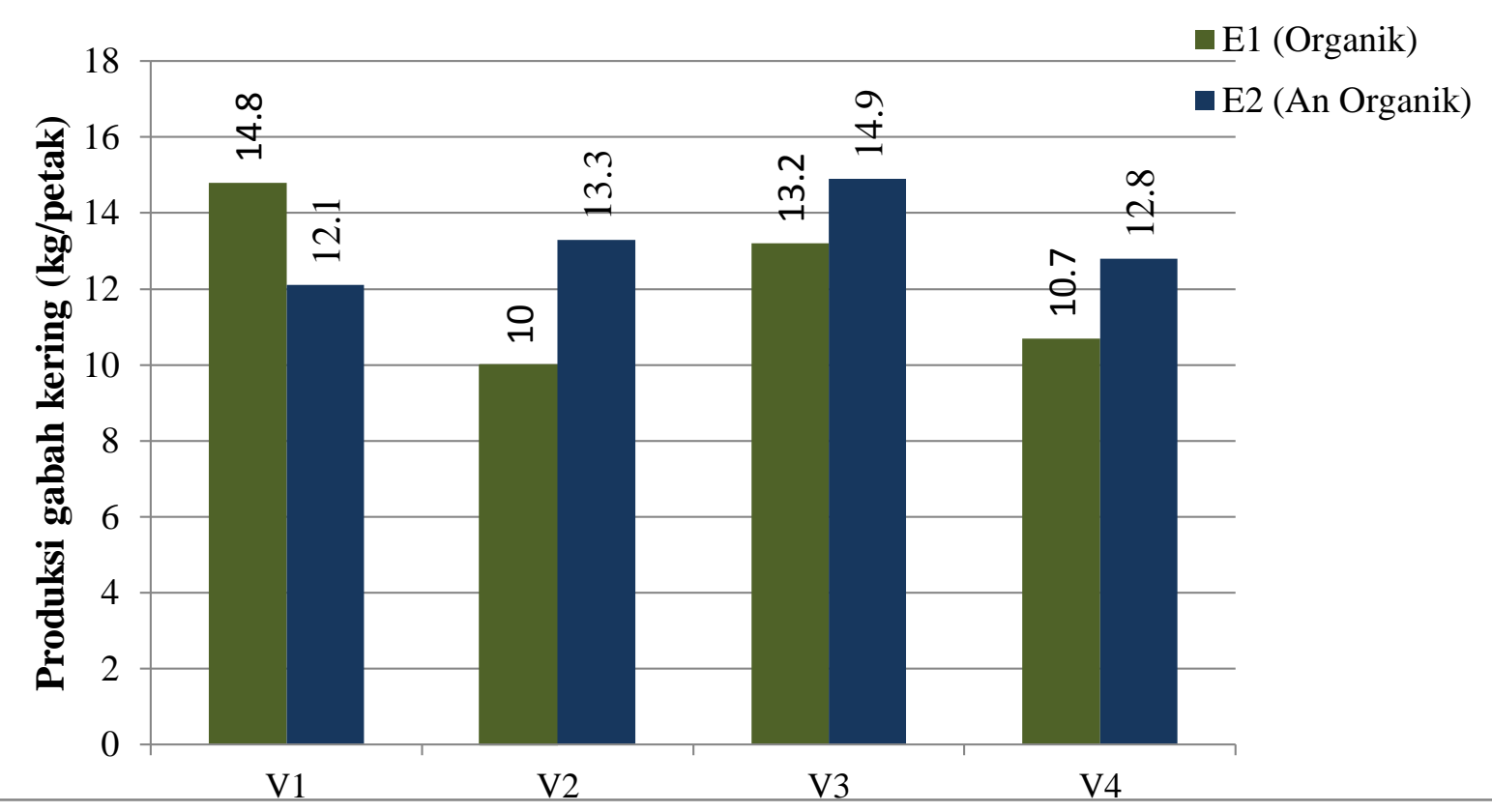

Gambar 2. Rata - rata produksi per petak beberapa varietas padi pada ekosistem sawah masukan bahan organik dan anorganik.

Berdasarkan Gambar 2, rata - rata tertinggi pada varietas ciliwung $\left(\mathrm{V}_{3}\right)$ hasil per petak varietas padi ciherang $\left(\mathrm{V}_{1}\right)$ dibandingkan dengan varietas ciherang $\left(\mathrm{V}_{1}\right)$, cenderung lebih baik pada ekosistem sawah cisantana $\left(\mathrm{V}_{2}\right)$ dan towuti $\left(\mathrm{V}_{4}\right)$.

masukan bahan organik $\left(\mathrm{E}_{1}\right)$ dibandingkan dengan varietas cisantana $\left(\mathrm{V}_{2}\right)$, ciliwung $\left(\mathrm{V}_{3}\right)$, dan towuti $\left(\mathrm{V}_{4}\right)$, selain itu produksi gabah perpetak terendah pada varietas cisantana $\left(\mathrm{V}_{2}\right)$, sedangkan pada ekosistem sawah masukan bahan anorganik $\left(\mathrm{E}_{2}\right)$ ada kecenderungan produksi gabah perpetak

\section{Hasil Gabah Kering per Hektar}

Hasil pengamatan produksi gabah kering per hektar menunjukkan beberapa varietas padi dan ekosistem sawah masukan bahan organik dan anorganik berpengaruh tidak nyata. 


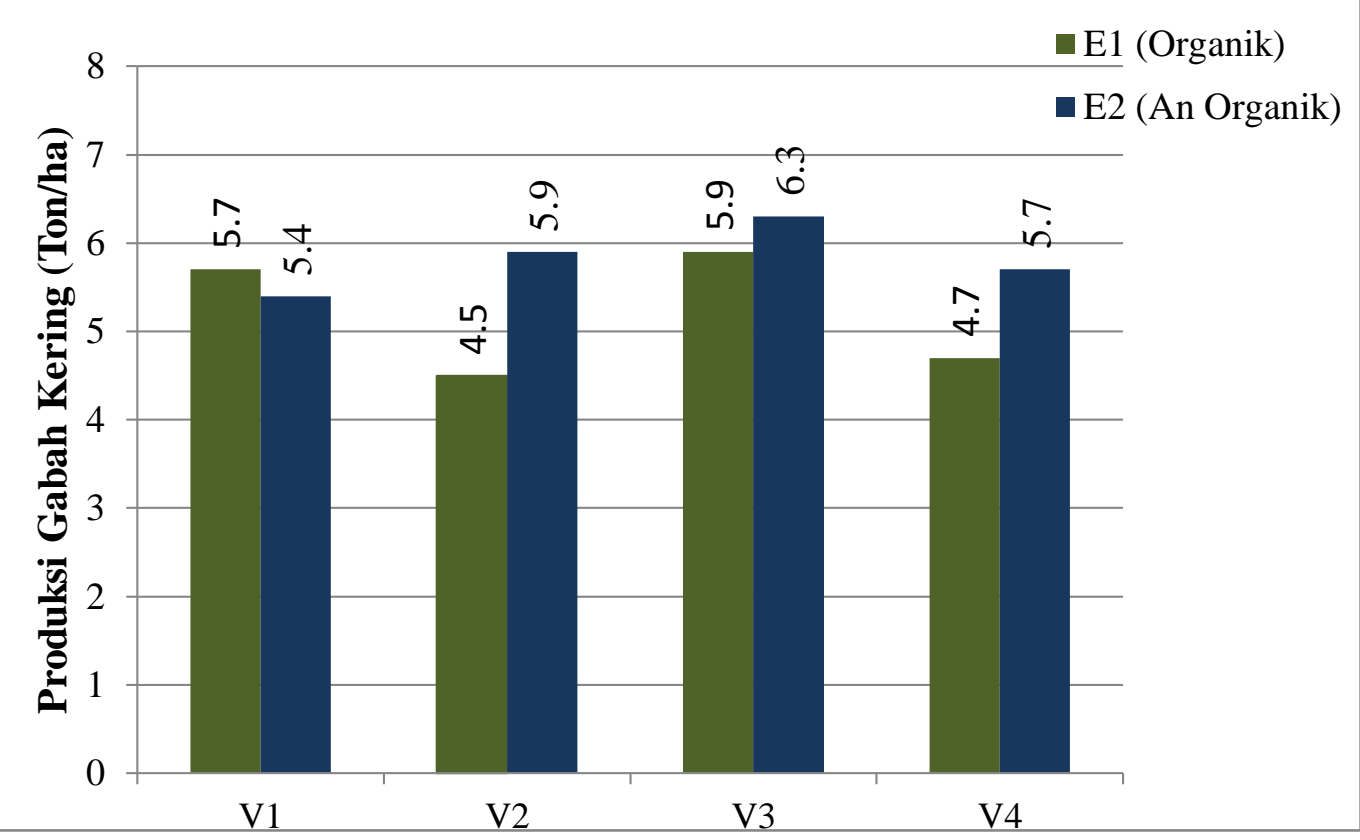

Gambar 3. Rata - rata produksi per hektar beberapa varietas padi pada ekosistem sawah dengan bahan organik dan anorganik.

Berdasarkan Gambar 3, rata - rata bahwa populasi dan intensitas serangan hasil per hektar varietas padi ciliwung $\left(\mathrm{V}_{3}\right)$ penggerek batang lebih tinggi pada semua cenderung lebih baik pada ekosistem sawah masukan bahan organik $\left(E_{1}\right)$ dibandingkan dengan varietas ciherang $\left(\mathrm{V}_{1}\right)$, cisantana $\left(\mathrm{V}_{2}\right)$, dan towuti $\left(\mathrm{V}_{4}\right)$. Selain itu produksi gabah perhektar terendah pada varietas cisantana $\left(\mathrm{V}_{2}\right)$. Sedangkan pada ekosistem sawah masukan bahan anorganik $\left(\mathrm{E}_{2}\right)$ ada kecenderungan produksi gabah perhektar tertinggi pada varietas ciliwung $\left(\mathrm{V}_{3}\right)$ dibandingkan dengan varietas ciherang $\left(\mathrm{V}_{1}\right)$, cisantana $\left(\mathrm{V}_{2}\right)$ dan towuti $\left(\mathrm{V}_{4}\right)$.

\section{Pembahasan}

Populasi hama penggerek batang dan intensitas serangan hama penggerek batang berdasarkan hasil penelitian yang disajikan pada Tabel 1 dan Gambar 1 menunjukkan varietas yang ditanam pada ekosistem sawah masukan bahan organik dibandingkan sawah masukan anorgank. Hal ini sejalan dengan penelitian Hadi (2015) menunjukkan bahwa penggerek batang padi cenderung lebih memilih ekosistem sawah organik dibandingkan sawah anorganik, walaupun fluktuasinya sepanjang tahun memiliki pola yang cenderung sama.

Perilaku penggerek batang padi berbeda dalam setiap varietas dan tingkat keseimbangan populasi penggerek batang padi di suatu daerah dapat berubah bila terjadi perubahan varietas (Ngatimin, 2005). Populasi penggerek batang padi mulai dari pengamatan 45-75 hst terus menurun, hal ini 
diduga karena pada fase reproduksi tanaman padi mengalami perubahan sifat fisiologis. Menurut Anwar dan Budiyanto (2013), populasi penggerek batang padi pada fase reproduksi semakin turun karena tanaman padi mulai kekurangan cairan sehingga batang yang menyebabkan hama penggerek batang padi kurang menyukainya.

Penelitian Hadi $d k k$ (2013) juga menunjukkan bahwa keanekaragaman penggerek batang di ekosistem sawah organik relatif tinggi terutama pada saat tanaman padi memasuki fase reproduktif.

Varietas towuti merupakan varietas dengan kategori ketahanan agak tahan, sedangkan tiga varietas lainnya memberikan respon yang lebih tinggi yaitu termasuk dalam kategori tahan (Gambar 1). Semua tanaman yang di uji terserang oleh penggerek batang padi, tetapi pada varietas towuti memiliki ketahanan yang lebih kuat daripada varietas ciherang, cisantana dan ciliwung karena intensitas serangannya rendah dan populasi yang menyerang lebih sedikit. Faktor yang mempengaruhi tanaman yang diuji yaitu mempunyai zat kimia tertentu sehingga mempengaruhi hama penggerek batang. Tetapi, kandungan kimia pada tanaman uji belum diketahui.

Intensitas serangan dan banyaknya populasi hama penggrek batang berpengaruh terhadap hasil produksi beberapa varietas yang diuji. Pada Gambar 3 menunjukkan bahwa rata-rata hasil perhektar varietas padi ciliwung $\left(\mathrm{V}_{3}\right)$ 5,9 ton/ha dan 6,3 ton/ha pada ekosistem sawah organik dan anorganik cenderung lebih banyak dibandingkan dengan varietas ciherang $\left(\mathrm{V}_{1}\right)$ dengan ratarata 5,7 ton/ha dan 5,4 ton/ha, varietas cisantana $\left(\mathrm{V}_{2}\right)$ dengan rata-rata 4,5 ton/ha dan 5,9 ton/ha serta pada varietas towuti $\left(\mathrm{V}_{4}\right)$ dengan rata-rata hasil 4,7 ton/ha dan 5,7 ton/ha. Rendahnya hasil produksi ini disebabkan oleh adanya serangan hama. Menurut Suharto dan Usyati (2009), kerugian hasil yang disebabkan oleh setiap persen gejala beluk berkisar 1-3\% dengan rata-rata 1,2\%. Damayanti dkk (2015) juga menyatakan bahwa kehilangan hasil akibat serangan hama penggerek batang padi dapat mencapai $10-30 \%$ dan serangan berat dapat menyebabkan puso.

Penelitian Carsono at al (2017) menunjukkan bahwa ketahanan padi transgenik DB 1, Taichung-65, IR64 dan Ciherang terhadap penggerek batang padi ( $S$ cirpophaga incertulas ) merupakan padi yang rentan dengan skala 9.

Sampai saat ini belum pernah dilakukan pengembangan penelitian secara utuh yang berkaitan dengan diversitas populasi di ekosistem sawah organik dan anorganik. Dengan diminimalkannya penggunaan bahan kimia pada sawah 
organik, baik dalam bentuk pupuk maupun pestisida, tentunya memberi peluang meningkatnya diversitas populasi hama penggerek batang, dibandingkan di sawah anorganik yang masih menggunakan bahan kimia sintetis dalam bentuk pupuk maupun pestisida.

\section{KESIMPULAN}

- Varietas padi towuti yang ditanam pada ekosistem sawah masukan bahan anorganik memiliki tingkat ketahanan terhadap hama penggerek batang padi yang lebih baik

- Intensitas serangan dan populasi penggerek batang pada ekosistem sawah masukan bahan organik lebih tinggi dibandingkan pada ekosistem sawah masukan bahan anorganik

- Interaksi antara varietas padi dan jenis ekosistem sawah (masukan bahan organik dan anorganik) berpengaruh tidak nyata terhadap intensitas hama penggerek batang.

\section{UCAPAN TERIMA KASIH}

Ucapan terima kasih kepada Bapak H. Bahar atas izin penggunaan sawah miliknya sebagai lokasi penelitian. Ucapan terima kasih juga kepada Dr. Ir. H. Sudirman Numba, M.S dan Dr. Ir. H. Abdullah, M.Si yang telah membantu dan membimbing dalam proses penyusunan jurnal.

\section{DAFTAR PUSTAKA}

Anwar, H., dan S. Budiyanto. 2013. Identifikasi Populasi Hama Penggerek Batang Padi di Lokasi SL-PTT di Kabupaten Banjarnegara. Seminar Nasional. Balai Pengkajian teknologi Pertanian (BPTP) Jawa Tengah

[BPS] Badan Pusat Statistik, 2017. Produksi tanaman padi tahun 2011-2015. Sulawesi Tengah.

Carsono N, Mangatur I, Hasan U F, Sari S, Susniahti N, Hersanti, Baehaki S E. 2017. Ketahanan padi Transgenik D B 1 terhadap penggerek batang padi kuning Scirpophaga incertulas Walker (Lepidoptera: Pyralidae), [diunduh 2019 oktober 23], Jurnal.unpad.ac.id

Chakraborthy, K. 2011. Extent of Yellow stem borer Scirpophaga incertulas (Walker) infestation under different proportional application of organic and inorganic fertilizer in paddy cultivar Swarna Mashuri (MTU 7029). Academic Journal of Entomology. 4(1): 710.

Chandramani, P, R.Rajendran, C Muthiah, and C Chiniah. 2010. Organic source induced silica on leaf folder, stem borere, and gall midge population and rice yield. Journal Biopesticides. 3(2): 423-427.

Damayanti, E., G. Mudjiono dan S. Karindah. 2015. Perkembangan Populasi Larva Penggerek Batang dan Musuh Alaminya pada Tanaman Padi (Oryza sativa L.) PHT. HPT, 3(2): 1824

Hadi M. 2015. Pertanian organik suatu alternative pengelolaaan ekosistem sawah yang sehat, alami dan ramah lingkungan. [diunduh 2020 januari 19]. www.neliti.com 
Hadi M. 2015. Populasi penggerek batang padi pada ekosistem sawah organik dan sawah anorganik [diunduh 2019 oktober 22]. Https://ejournal.undip.ac.idHadi $\mathrm{M}$, Soesilohadi R C H, Wagiman F X, Suhardjono Y R. 2013. Keragaman Jenis dan Kelimpahan Populasi Penggerek Batang Padi dan Serangga Lain Berpotensi Hama Pada Ekosistem Sawah Organik. Jurnal BIOMA, Desember 2013 Vol. 15, No. 2, Hal. 58-63

Kartohardjono A, Kertoseputro D, Suryana T. 2008. Hama padi potensial dan pengendaliannya. Balai Besar Penelitian Tanaman Padi

Munakata, K. and D. Okamoto. 1967. The Major Insect Pests of the Rice Plant. Baltimore: Johns Hopkins Press.

Ngatimin, S. N. A. 2005. Pengaruh Pola Tanam Campuran Beberapa Varietas Padi Terhadap Populasi dan Intensitas Serangan Beberapa Hama Tanaman Padi. Sains \& Teknologi, 5(2): 85-89.

Pajarina A R. 2014. Perkembangan populasi hama pada sistem padi organik dan sistem padi konvensional di Ngawi, Jawa Timur. [Skripsi]. Fakultas Pertanian. Institut Pertanian Bogor. 